Adrianna Smurzyńska

\title{
DUSZA-UMYSŁ-CIAŁO. ROZWAŻANIA NAD TRIADYCZNĄ ANTROPOLOGIĄ
}

Sam Bóg pokoju niech uświęca was całych, aby nietknięty duch was, dusza i ciało bez zarzutu zachowaty się na przyjście Pana naszego, Jezusa Chrystusa. $\quad(1 \text { Tes } 5,23)^{1}$

W filozofii człowieka istnieje wiele rozważań na temat jego duchowej, psychicznej czy cielesnej natury. Wielu filozofów zajmowało się jednym z tych komponentów, zaniedbując pozostałe. Tak powstały antropologie monistyczne - zarówno fizykalne, jak i spirytualistyczne. Prowadziło to do stworzenia zniekształconego obrazu człowieka - jawił się on nierzadko jako maszyna, wytwór ewolucji czy bezcielesny anioł. Takie skrajne poglądy są szkodliwe, mogą być jednak przydatne w rozwijaniu bogatszych antropologii.

O krok dalej idą antropologie dualistyczne - bardziej radykalne, takie jak dualizm platoński lub kartezjański², i mniej radykalne, jak na przykład

${ }^{1}$ Korzystam z wydania: Biblia Jerozolimska, Pallottinum, Poznań 2006.

${ }^{2}$ Zob. B. Dobroczyński, Szlachetny banita na wygnaniu. Czy jest miejsce dla duszy w psychologii?, „Znak” 2009, nr 644, s. 13. 
hylemorfizm ${ }^{3}$ czy współczesny emergentyzm ${ }^{4}$. Ze względu na niemożliwość całkowitego rozdzielenia materii i formy w hylemorfizmie, traktuje się czasem tę koncepcję jako pogląd odmienny zarówno od monizmu, jak i dualizmu. Jednak ze względu na skupienie się w nim na dwóch elementach człowieka - duszy i ciele - w niniejszej pracy hylemorfizm traktowany będzie jako odmiana dualizmu. Rozpatrywanym problemem w antropologiach dualistycznych jest zazwyczaj relacja dusza-ciało lub umysł-ciało (ewentualnie umysł-mózg). Takie rozważania budzą wiele problemów, dlatego współcześnie prym wiodą zgrabniejsze teorie fizykalistyczne, oparte na neurobiologii.

Uznanie jednak, że potrzebujemy prostszej teorii, nie rozwiązuje problemu. Pozostaje nadal wiele zjawisk, takich jak jakościowy charakter świadomości czy zjawisko sztuki, których nie da się do końca wyjaśnić podpierając się biologią. Nie mówiąc już o doświadczeniach religijnych, które biologowie próbują bezskutecznie badaćs.

W swojej pracy chciałabym zaproponować triadycznie spojrzenie na człowieka oparte na antropologii hebrajskiej. Jest ona o tyle ciekawa, że w jej ramach zdaje się istotnym pytanie o relację duszy i umysłu, której próbę opisu ciężko znaleźć w dostępnej literaturze. Doświadczenia współczesnego człowieka pokazują jednak, jak ważne jest rozważanie tej kwestii. Będę starała się to udowodnić w trakcie moich rozważań.

Rozpocznę od przywołania teorii, których autorzy starają się sprowadzić jeden z tych komponentów do innego. Przywołam triadyczną antropologię pokazując jej silny związek ze współczesną psychologią. Odnotuję również przypadki z zakresu medycyny, które mogą pomóc w zrozumieniu poruszanego zagadnienia. Pod koniec artykułu postaram się pokazać, jakie skutki praktyczne mogą płynąć z rozważań antropologicznych.

${ }^{3}$ Pogląd św. Tomasza z Akwinu - złożenie z materii (ciała) i formy (duszy). Zob. S. Swieżawski, Święty Tomasz na nowo odczytany, Znak, Kraków 1983, s. 99-100.

${ }^{4}$ Współczesny pogląd, według którego to, co psychiczne, powstaje z tego, co fizyczne. Co więcej - umysł oddziałuje na ciało i nie daje się do niego zredukować. Zob. J. Bremer, Problem umyst-ciało, Wydawnictwo WAM, Kraków 2001, s. 127.

${ }^{5}$ Zob. B. Wojcik, Neuroteologia - fakty i mity, „Zagadnienia Filozoficzne w Nauce” 2003, nr 33, s. 150-153. 


\section{OD DUSZY DO MÓZGU}

2.1. UMYS JAKO WeAdZA DUSZY. Dusza od początku była uznawana za coś odrębnego od ciała - odpowiedzialna była za ciągłość osobowości i tożsamości ${ }^{6}$. $\mathrm{Z}$ biegiem czasu mówienie o duszy zaczęto zastępować mówieniem o umyśle ${ }^{7}$, odwołując się raczej do czynnika fizykalnego (niż do pozaziemskiego) jako genezy duszy i jej przeznaczenia. Umysł zaczęto traktować jako coś wytworzonego przez ciało i jednocześnie, podobnie jak ciało, śmiertelnego. Zmianę terminologii można wyraźnie zauważyć u Kartezjusza, który w Medytacjach o pierwszej filozofii ${ }^{8}$ zamiennie używa terminów „dusza”, „umysł”, „intelekt”, stopniowo coraz rzadziej mówiąc o pierwszym z nich.

W starożytności i średniowieczu umysł, rozum czy intelekt uznawano za władzę duszy ${ }^{9}$. Była to zazwyczaj jedna z jej funkcji - najwyższa, charakteryzująca człowieka. Miała ona kluczową rolę w wyjaśnianiu tego, kim jest człowiek, ale nie prowadziła do zrozumienia tego, czym jest dusza.

Tomasz z Akwinu pisał, że władza duszy nie jest tym samym, co jej isto$\mathrm{ta}^{10}$. Stwierdził on, że intelekt jest jedynie władzą duszy ${ }^{11}$, uznawaną zwykle za naczelną, ale nie jedyną. Rozum nie jest bezpośrednią zasadą działania człowieka. Jego istnienie nie wyraża się jedynie w sferze intelektualnej, dlatego nie można wyjaśnić natury duszy poprzez badanie samego umysłu ${ }^{12}$.

2.2. DUSZA JAKO POCHODNA MóZGU. Współcześnie można zauważyć skłonność niektórych neurobiologów do utożsamiania duszy z wytworami mózgu. Neuroteologia stara się badać neurobiologiczne podstawy

\footnotetext{
${ }^{6}$ Zob. B. Dobroczyński, dz. cyt., s. 12.

${ }^{7}$ Zob. tamże, s. 16.

${ }^{8}$ Zob. R. Descartes, Medytacje o pierwszej filozofii, przeł. K. i A. Ajdukiewicz, Antyk,
} Kęty 2011.

${ }^{9}$ Zob. V. Possenti, Spór o jedność człowieka i wyzwania nowego naturalizmu. Dusza-umyst - ciało, przeł. A. Gudaniec, [w:] Dusza Umyst Ciało. Spór o jedność bytowa człowieka, red. A. Maryniarczyk, K. Stępień, Polskie Towarzystwo Tomasza z Akwinu, Lublin 2007, s. 117.

${ }^{10}$ Zob. Tomasz z Akwinu, Traktat o człowieku, przeł. S. Swieżawski, Wydawnictwo Antyk, Kęty 2000, s. 172-173.

\footnotetext{
${ }^{11}$ Zob. tamże, s. 282.

${ }^{12}$ Zob. tamże, s. 282-283.
} 
religii i duchowości ${ }^{13}$. Doświadczenia religijne badane są technikami neuroobrazowania (szczególnie metodą SPECT - Single Photon Emissiom Computerised Tomograph ${ }^{14}$. Zdaje się jednak, że samo pokazanie obszarów w mózgu, które aktywują się w trakcie takich przeżyć, nic nam nie mówi o duszy. Potwierdza to tylko, że jest ona w pewien sposób zespolona z ciałem, a nie - że jest jego produktem. Warto pamiętać, że przyczynowość (oddziaływanie) nie jest tym samym, co korelacja (współwystępowanie) zjawisk.

\section{3. ŚREDNIOWIECZNIE O CZEOWIEKU}

Cofnijmy się o kilka wieków. Pisma średniowiecznych myślicieli okazują się bardzo przydatne $\mathrm{w}$ rozwiązywaniu problemu psychofizycznego oraz innych zagadnień z zakresu filozofii umysłu.

3.1. Dusza JAKO HARMONia, UMYSE JAKO HARMONIA. Rozważając różne teorie na temat natury duszy Nemezjusz z Emezy w tekście 0 naturze człowieka przywołał pogląd Dicearcha i Simmiasa, że dusza jest harmonią ${ }^{15}$. Krytykując tę teorię zauważył, że dusza nie może podlegać zmianom - zaburzona byłaby bowiem jej tożsamośćc ${ }^{16}$. Natomiast harmonia jest zawsze harmonią pewnych części - zmieniałaby się zatem w miarę, jakbyśmy dorastali.

Nemezjusz przywołał również teorię Galena na temat istoty duszy ${ }^{17}$. Mimo że Galen nie sformułował swojej teorii wprost, z jego pism Nemezjusz wnosi, że utożsamiał on duszę ze stanem zrównoważenia humorów ${ }^{18}$.

${ }^{13}$ Zob. F. Rutaganira, Neurotheology: Confirming the Existence of a Naturally Mystical Mind, Prized Writing 2006-2007, http://prizedwriting.ucdavis.edu/past/2006-2007/Rutaganira, (dostęp: 11 VIII 2012).

${ }^{14}$ Zob. tamże, s. 175.

${ }^{15}$ Zob. Nemezjusz z Emezy, O naturze ludzkiej, przeł. A. Kempfi, PAX, Warszawa 1982, s. 38.

${ }^{16}$ Zob. tamże, s. 40.

${ }^{17}$ Zob. tamże, s. 39.

${ }^{18}$ Galen (za Hipokratesem) wyróżniał cztery humory (soki, płyny): krew, flegmę, czarną i żółtą żółć. Humory odpowiedzialne były za temperament człowieka oraz skłonności do zapadania na różnego rodzaju choroby. Zob. E. Trillat, Historia histerii, przeł. Z. Podgórska-Klawe, E. Jamrozik, Wydawnictwo Ossolineum, Wrocław, Warszawa, Kraków 1993, s. 21-22; R. Gerrig, P. Zimbardo, Psychologia i życie, przeł. J. Radzicki i inni, Wydawnictwo Naukowe PWN, Warszawa 2008, s. 428. 
Zrównoważenie to jednak musi być szczególnego rodzaju - gdyby bowiem każde zrównoważenie było duszą, to każde ciało by ją posiadało. Nie byłoby zatem ciał nieożywionych ${ }^{19}$.

Inną kwestią jest to, że zrównoważenie podlega zmianom „wraz z wiekiem, porą roku i sposobem odżywania się"20. To jest jeden z głównych argumentów, jaki podaje Nemezjusz sprzeciwiając się uznaniu duszy za stan zrównoważenia. Bez wątpienia nie można zatem uznać, że dusza jest harmonią.

Natomiast takim zmianom podlega bez wątpienia umys ${ }^{21}$. Rodzimy się bowiem z pewnym uposażeniem układu nerwowego, kilkoma wrodzonymi instynktami i regułami, które kształtują się w rozwoju osobniczym. Roboczo można uznać umysł za harmonię zarówno ciała, jak i duszy. Przy niedostatkach cielesnych, szczególnie przy zaburzeniach w funkcjonowaniu układu nerwowego, umysł nie działa sprawnie. Podobnie jest - choć trudniej to stwierdzić - w przypadku różnego rodzaju rozterek natury duchowej.

3.2. A POlinariusz - DUSza, UMYse i CiaŁo. Plotyn uważał, że myślenie jest czymś innym niż dusza ${ }^{22}$. Trychotomiczny, hebrajski podział człowieka na ciało, duszę i ducha był popularny jeszcze we wczesnym chrześcijaństwie. Ten podział wykorzystał Apolinary ${ }^{23}$, biskup Laodycei. Korzystając z niego, starał się wyjaśnić naturę Chrystusa ${ }^{24}$. Uważał, ze Boski Logos był w nim umysłową częścią duszy, ciało natomiast tym, co ludzkie. Łącznikiem między ciałem i Logosem miała być psyche dusza pojmowana jako ośrodek uczyć i emocji. Ta interpretacja wzbudziła liczne kontrowersje, ponieważ postulowała istnienie czegoś pośredniego, jakiejś „trzeciej substancji”. Doktryna ta została zatem uznana za herezję i potępiona na Pierwszym Soborze Konstantynopolitańskim w 381 roku.

${ }^{19}$ Zob. Nemezjusz z Emezy, dz. cyt., s. 40.

${ }^{20}$ Tamże, s. 40.

${ }^{21}$ Zob. R. Gerrig, P. Zimbardo, Psychologia..., dz. cyt., s. 316-324.

${ }^{22}$ Zob. Nemezjusz z Emezy, dz. cyt., s. 16.

${ }^{23}$ Zob. Apolinarius, Demonstracja Bożego wcielenia, podaję za: Nemezjusz z Emezy, dz. cyt., s. 16.

${ }^{24}$ Zob. S. Duda, Dusza do zbawienia koniecznie potrzebna, „Znak” 2009, nr 644, s. 32-33. 
$\mathrm{Z}$ biegiem lat, trychotomiczna antropologia stawała się coraz mniej zrozumiała i została wyparta przez dualizm psychosomatyczny ${ }^{25}$.

\section{ANTROPOLOGIA HEBRAJSKA}

Połączenie chrześcijaństwa z myślą grecką doprowadziło do zepchnięcia biblijnej antropologii na margines rozważań o człowieku ${ }^{26}$. Jak myślę, warto jednak powrócić do tego rozwiązania. Pozwala ono bowiem na szerszą perspektywę przy rozważaniu natury człowieka.

W hebrajskiej antropologii nie istnieje dualizm dusza-ciało ${ }^{27}$. Hebrajski określa żywego człowieka posługując się terminami: nefesz (dusza) albo basar (ciało), które dotyczą jednej i tej samej rzeczywistości - człowieka żyjącego na tym świecie ${ }^{28}$. Z równym stopniem prawdziwości można powiedzieć ,jesteśmy ciałami”, jak i ,jesteśmy duszami”. Człowiek zawsze pojawia się jako całośćc .

W systemie dualistycznym zazwyczaj uczucia czy funkcje organiczne przypisuje się ciału, natomiast wszystko, co należy do porządku psychicznego, przypisujemy duszy ${ }^{30}$. W języku hebrajskim namiętności, funkcje organiczne czy doznania odnoszone są zarówno do duszy, jak i zmysłów. Myśli i uczucia są natomiast związane ze zmysłami i partiami cielesnymi. Duszy przypisuje się funkcje cielesne, natomiast części ciała odgrywają rolę psychologiczną $^{31}$. W ramach hebrajskiego pojmowania uczuć i namiętności (tak jak w przypadku współczesnej psychologii) nie oddziela się części psychologicznej od części somatycznej ${ }^{32}$.

${ }^{25}$ Zob. tamże, s. 33.

${ }^{26}$ Zob. tamże, s. 32.

${ }^{27}$ Zob. C. Presmontant, Eseje o myśli hebrajskiej, przeł. M. Tarnowska, Znak, Kraków 1996, s. 107-108; 116.

${ }^{28}$ Zob. tamże, s. 117.

${ }^{29}$ Zob. D. Czaja, Anatomia duszy. Figury wyobraźni i gry językowe, Wydawnictwo UJ, Kraków 2005, s. 90.

${ }^{30}$ Zob. C. Presmontant, dz. cyt., s. 124.

${ }^{31}$ Zob. tamże, s. 125.

${ }^{32}$ Zob. tamże, s. 126. 
W starotestamentowym pojęciu człowieka, między nefesz, basar i ruah (duch) nie ma zasadniczej istotowej różnicy - są to różne sposoby spojrzenia na ten sam byt ${ }^{33}$. Człowiek cały czas pojmowany jest jako jedność.

\section{UMYSŁ I DUSZA A MEDYCYNA}

Ciekawym zjawiskiem występującym we współczesnej filozofii jest podpieranie bądź obalanie twierdzeń metafizycznych w oparciu o przypadki medyczne (szczególnie psychiatryczne). W takich sytuacjach istnieje niebezpieczeństwo generalizacji, jednak wydaje się, że korzyści, jakie można wyciągnąć z ich analizy, są o wiele bardziej znaczące.

Przy rozważaniu relacji dusza-umysł, ciekawe jest rozważanie przypadków chorobowych związanych z utratą pamięci i tożsamości. Oliver Sacks w swojej książce Mężczyzna który pomylił swoją żonę z kapeluszem podaje charakterystykę dwóch mężczyzn cierpiących na amnezję. Przy każdym z nich zadaje pytanie, czy jest możliwie, żeby „choroba mogła pozbawić duszy”34.

Pierwszym z nich był Jimmy ${ }^{35}$ - cierpiący na chorobę Korsakowa, objawiającą się utratą pamięci od pewnego okresu życia (amnezją następczą). Nie był on w stanie funkcjonować w świecie, ponieważ nie potrafił niczego nowego zapamiętać. Takie zaburzenie pamięci skutkuje w dużym stopniu zaburzeniem tożsamości - chory nie rozpoznaje swoich zapisków jako swoich, nie identyfikuje emocji przelanych na papier ze sobą w danym momencie. Jimmy jednak całkiem inaczej zachowywał się będąc w kaplicy wykazywał się wytężoną uwagą i koncentracją, widać było, jak mocno przeżywa Eucharystię. „Pamięć, aktywność umysłowa, sam umysł nie mogły go utrzymać w całości; ale uwaga i działanie w sferze duchowej mogły go stworzyć" ${ }^{36}$.

Sacks podaje jednak inny przypadek, w którym pytanie o istnienie duszy zdaje się bardziej problematyczne. William Thompson cierpiał na cięższą odmianę zespołu Korsakowa - nie pamiętał niczego dłużej niż kilka

${ }^{33}$ Zob. D. Czaja, dz. cyt., s. 92.

${ }^{34}$ O. Sacks, Mężczyzna, który pomylił swoją żonę z kapeluszem, przeł. B. Lindenberg, Wydawnictwo Zysk i S-ka, Poznań 2008, s. 62.

${ }^{35}$ Zob. tamże, s. 44-69.

${ }^{36}$ Tamże, s. 63. 
sekund $^{37}$. Wskutek tego stracił poczucie tożsamości - co chwilę tworzył nową historię siebie, w ciągu paru minut potrafił również potraktować jedną osobę jako kilkanaście różnych postaci. Tak samo odnosił się do rzeczywistości, jak i do fikcji, które tworzył. U Williama jednak, w przeciwieństwie do Jimmiego, nie występowały momenty, kiedy ujawniała się jego duchowa strona. Stracił on jakąkolwiek zdolność odczuwania. W kaplicy zachowywał się tak samo, jak poza nią. Nawet siostry zakonne były tym faktem zaniepokojone i mniej pewnie mówiły o duchowej stronie Williama niż w przypadku Jimmiego.

Nie jest to bynajmniej powód do utożsamiania duszy z funkcją umysłu i argument za stwierdzeniem, że dusza „znika”, kiedy umysł nie działa sprawnie. Jednak w przypadkach chorobowych dusza może nie mieć możliwości ujawnienia się inaczej niż poprzez umysł.

Pisał o tym już Nemezjusz:

Jeśli zaś duszą byłaby harmonijna zbieżność zdrowia, siły i piękna, niepodobieństwem byłoby istnienie ludzi chorych, słabych czy zniekształconych. Często się zaś przecież zdarza, że nie tylko jedno, ale wszystkie trzy z tych zrównoważeń zostają stracone, a jednak człowiek nadal żyje. Bywa wszak, że jeden i ten sam człowiek na raz jest i zniekształcony, i słaby, i chory. Na pewno zatem dusza nie utożsamia się z prawidłowym zrównoważeniem ciała ${ }^{38}$.

\section{TRZY KOMPONENTY CZEOWIEKA}

W antropologii hebrajskiej mamy wydzielone w człowieku trzy komponenty: ducha, duszę i ciało. We współczesnych rozważaniach skłonna jestem jednak przystać na podział: dusza, umysł, ciało. Wiele bowiem funkcji, które w starożytności czy średniowieczu przypisywano duszy (szczególnie funkcji poznawczych), przypisujemy obecnie umysłowi. Nie znaczy to jednak, że powinniśmy zastąpić pojęcie duszy pojęciem umysłu. Nie można nie brać pod uwage współczesnej działalności naukowo-filozoficznej, w ramach której - w przypadku większości modeli antropologicznych - wyraźnie rozgranicza się sferę duchową od poznawczej.

\footnotetext{
${ }^{37}$ Zob. tamże, s. 151-161.

${ }^{38}$ Nemezjusz z Emezy, dz. cyt., s. 41.
} 
6.1. GdzIE DUSZA, A GDZIE UMySŁ? Przywołane stanowiska pokazują, że pytanie, jaka jest relacja duszy do umysłu, nie jest proste. Przytaczane koncepcje wyznaczają jednak pewną drogę, którą można podążać w rozważaniach metafizycznych. Dusza jest bowiem w pewien sposób związana i z ciałem (kiedy jej działania odzwierciedlają się w funkcjonowaniu mózgu), i z umysłem ${ }^{39}$ (kiedy wyraża się zarówno przez intelekt, jak i emocje). Dusza nie może być harmonią, bo wtedy podlegałaby zmianie; jednak taką harmonią wydaje się umysł. Antropologia hebrajska jeszcze bardziej kładzie nacisk na nierozerwalność wszystkich trzech komponentów człowieka - nie da się jednoznacznie określić, które z ludzkich zachowań przypisać można umysłowi, które duszy, a które ciału. Po raz kolejny wychodzi na jaw ich mocna korelacja.

Ksiądz Krzysztof Grzywocz w rozmowie z Wojciechem Eichelbergerem ${ }^{40}$ powiedział, że „duchowość nie jest izolacyjnie pojętą częścią człowieka”, a „to, co cielesne i psychiczne, wyraża to, co duchowe”" Wypowiedź ta mówi o silnej integralności poszczególnych elementów człowieka. Bez psychiki i ciała, dusza nie mogłaby się manifestować w świecie. Natomiast psychika jest ściśle zależna od cielesności. Dusza wbrew pozorom również:

Jeśli [ciało] jest dobrze ukonstytuowane, wspiera duszę i samo także jest w dobrej formie. Jeśli zaś jest ukonstytuowane źle, hamuje duszę i musi się ona wtedy rozruszać, by móc sprostać mankamentom swego instrumentu ${ }^{42}$.

6.2. Co Dla A NTROPOLOGil? Na początku mojej pracy stwierdziłam, że zarówno antropologie monistyczne, jak i dualistyczne nie są w stanie wyrazić tego, kim jest człowiek. Antropologia triadyczna idzie jeszcze dalej; w tym ujęciu sprowadzenie działań człowieka do sfery umysłowej, duchowej i cielesnej, z jednoczesnym uwzględnieniem ich oddziaływań,

${ }^{39}$ Mowa tu o współczesnym podejściu do umysłu, zgodnie z którym uczucia i emocje są jego składowymi w równym stopniu jak rozum czy percepcja.

${ }^{40}$ Zob. W. Eichelberger, K. Grzywocz, Spotkanie, „Więź” 2004, nr 2, s. 4-20.

${ }^{41}$ Zob. tamże, s. 10.

${ }^{42}$ Nemezjusz z Emezy, dz. cyt., s. 42. 
daje o wiele szerszy obraz człowieka. W ramach tej antropologii można znaleźć zarówno typowo biologiczne, ewolucyjne cechy człowieka jako gatunku homo sapiens sapiens, jak i duchowe, powiązane $\mathrm{z}$ transcendentnym charakterem duszy.

\section{BRAK ROZWIĄZANIA - ROZWIĄZANIEM}

Jak starałam się pokazać, jednoznaczne określenie zależności duszaumysł-ciało jest bardzo trudne. Ma to problematyczne konsekwencje nie tylko natury filozoficznej, ale i praktycznej ${ }^{43}$. Nie potrafiąc oddzielić tego, co duchowe, od tego, co cielesne, człowiek przeżywając trudności nie wie, czy pomocy szukać u psychologa, duchownego czy lekarza. Dlatego w ciągu ostatnich lat rozpowszechnia się leczenie integralne - człowiek jest często pod opieką zarówno przewodnika duchowego, jak i psychologa, a w cięższych przypadkach - również psychiatry. Natomiast uznanie monistycznej czy dualistycznej antropologii może nie prowadzić do rozwiązania problemów - można szukać pomocy u psychiatry, kiedy tak naprawdę potrzeba rozmowy z duchownym, lub odwrotnie.

Claude Presmontant napisał, że „umiejętność rozróżniania tego, co psychologiczne - cielesne - i tego, co duchowe, stanowi zasadę wszelkiego autentycznie chrześcijańskiego życia mistycznego" ${ }^{44}$. Nie każdemu jest jednak dane doświadczyć takiego życia, co nie znaczy, że nie może się ono stać naszym celem. Jeśli łatwiej jest nam funkcjonować w uporządkowanym świecie, to może czasem warto uporządkować s w ój świat.

Na gruncie filozofii chrześcijańskiej nie da się do końca poznać duszy (w sensie dyskursywnym) ${ }^{45}$. Świadomość jest jedynie jej narzędziem, zatem nawet jej refleksja nad samą sobą, której efektem jest samoświadomość, nie może doprowadzić do poznania duszy. Pytanie tylko, czy świadomość może poznać samą siebie. Gdy bowiem nakierowuje się na siebie, jej obiekt się zmienia - staje się ona jednocześnie aktem i przedmiotem swojego aktu.

\footnotetext{
${ }^{43}$ Zob. W. Eichelberger, K. Grzywocz, dz. cyt., s. 4-20.

${ }^{44}$ C. Presmontant, dz. cyt., s. 139.

${ }^{45}$ Zob. I. Kania, Duszy nasze wyobrażenia, „Znak” 2009, nr 644, s. 44.
} 
Co więcej, wątpliwe jest również poznanie ciała własnym ciałem - łatwo to zauważyć na podstawie badania osób z zaburzeniami propriocepcji ${ }^{46}$.

Być może nigdy nie uda nam się wypracować spójnej koncepcji człowieka. Nie znaczy to jednak, że nie możemy starać się takiej zbudować. Antropologia biblijna zdaje się $\mathrm{w}$ tym względzie o wiele bardziej pomocna niż dualizm psychofizyczny - być może rozważania powinny pójść raczej w kierunku rozjaśnienia wzajemnych zależności między duszą, umysłem i ciałem, a nie ich rozdziału. Kolejny raz okazuje się, że współcześni filozofowie winni szukać inspiracji w teoriach średniowiecznych, a nie jedynie podpierać się współczesną nauką (o której jednak nie można zapominać).

\section{SOUL, MIND AND BODY. CONSIDERING TRIADIC ANTROPOLOGY}

\section{SUMMARY}

This article considers triadic view of human, based on Hebraic anthropology. At the begging, there are presented monistic and dualistic anthropologies - ancient, medieval and contemporary. Then, they are contrasted with triadic anthropology, which suits better to achievements of contemporary psychology. At the end, the author puts forward an opinion about practical implications of triadic anthropology.

\section{KEYWORDS}

dualism, Hebraic anthropology, medieval anthropology, mind, monism, soul

${ }^{46}$ Propriocepcja - percepcja własnego ciała, czucie wewnętrzne. Zob. O. Sacks, Mężczyzna..., dz. cyt., s. 70. 